\title{
THERMAL STABILITY CHANGING CAUSED BY CHROMIUM (III) IN THE CARBONATED MAGNESIUM-ALUMINUM HYDROTALCITE
}

\section{ALTERAÇÃO DA ESTABILIDADE TÉRMICA CAUSADA PELO CRÔMIO (III) NA HIDROTALCITA CARBONATADA DE MAGNÉSIO-ALUMÍNIO}

\author{
N. B. F. AQUINO ${ }^{1}$, D. B. MORAIS ${ }^{1}$, A. C. AQUINO ${ }^{1}$, G. V. BARBOSA ${ }^{1 *}$ and A. A. CAVALHEIRO ${ }^{1}$ \\ ${ }^{1}$ Universidade Estadual de Mato Grosso do Sul, Laboratório Interdisciplinar de Materiais Avançados de Naviraí \\ (LIMAN), Naviraí, Mato Grosso do Sul, Brazil
}

*Corresponding author. Universidade Estadual de Mato Grosso do Sul, Laboratório Interdisciplinar de Materiais Avançados de Naviraí (LIMAN), Naviraí, Mato Grosso do Sul, Brasil, Phone: +55 (67) 99987-3216, e-mail address: grace.navi.21@ gmail.com (G.V. Barbosa).

\begin{tabular}{l} 
A R T I C L E I N F O \\
\hline Article history: \\
Received 2020-09-30 \\
Accepted 2020-12-12 \\
Available online 2020-12-12 \\
pa l avra - ch a ve \\
Argila Sintética \\
Hidrotalcita \\
Precipitação \\
Cristalização \\
Porosidade \\
ke y w o r $d s$ \\
Synthetic clay \\
Hydrotalcite \\
Precipitation \\
Crystallization \\
Porosity
\end{tabular}

\begin{abstract}
A B S T R A C T
There are several purposes for investigating hydrotalcite clays and one of them is due to its importance as an anionic adsorbent and ion exchanger, which make them capable of removing various pollutants from water. The most common hydrotalcite structure is based on double lamellar hydroxide of magnesium and aluminum, containing carbonate anions in the interlayer space. However, it is common to investigate the co-substitution of aluminum with other trivalent cations, especially transition metal cations, due to their binding properties. In this work, it was investigating the co-substitution of chromium (III) and aluminum in a sample of magnesium-aluminum carbonated hydrotalcite, comparing it with the same composition without this co-substitution. Thermal stability, crystallinity and morphology were investigated, showing that chromium contributes to the adsorptive capacity at low temperature.
\end{abstract}

R E S U M O

As pesquisas com argilas de hidrotalcita têm diversas finalidades e uma delas se deve à sua importância como adsorvente aniônico e trocador de ions, o que as tornam capazes de remover diversos poluentes da água. A estrutura de hidrotalcita mais comum é baseada em hidróxido duplo lamelar de magnésio e alumínio, contendo ânions carbonato no espaço interlamelar. No entanto, é comum investigar a cossubstituição do alumínio por outros cátions trivalentes, especialmente cátions de metais de transição, devido às suas propriedades ligantes. Neste trabalho, foi investigada a cossubstituição do alumínio com cromo (III) em uma amostra de hidrotalcita carbonatada de magnésio-alumínio, comparando-a com a mesma composição sem esta cossubstituição. Estabilidade térmica, cristalinidade e morfologia foram investigadas, mostrando que o cromo contribui para a capacidade adsortiva em baixa temperatura. 


\section{INTRODUCTION}

Hydrotalcite clay minerals are a class of anionic clays formed by Layered Double Hydroxide (LDH) with adsorbent properties and have compositions given by the general formula: $\mathrm{M}^{+2}{ }_{(1-\mathrm{x})} \mathrm{M}^{+3}{ }_{\mathrm{x}}\left(\mathrm{OH}^{-}\right)_{2}\left(\mathrm{~A}^{-\mathrm{n}}\right)_{\mathrm{x} / \mathrm{n}} \cdot \mathrm{yH}_{2} \mathrm{O}$, where $\mathrm{M}^{+2}$ and $\mathrm{M}^{+3}$ are metallic cations with reduced ionic rays and $\mathrm{A}^{-\mathrm{n}}$ are interlayer anions (Belloto et al., 1996).

The three-dimensional structure formed in hydrotalcites comes from the perpendicular interposition of lamellae, anchored by divalent or trivalent interlayer anions. In natural hydrotalcites, the most common interlayer anion is carbonate $\mathrm{CO}_{3}{ }^{-2}$, due to the greater affinity with cations of alkaline earth metals, such as the magnesium one. However, other inorganic and also organic anions can be inserted in the interlayer space, which makes the material versatile for several applications (Velu e Swamy, 1997; Yang et al., 2016).

The hydrotalcite possesses structure similar to $\mathrm{Mg}(\mathrm{OH})_{2}$ brucite, characterized by the Layered Double Hydroxide (LDH), but the magnesium can be partially replaced by other divalent cations, such as $\mathrm{Zn}^{+2}, \mathrm{Ca}^{+2}, \mathrm{Ni}^{+2}, \mathrm{Cu}^{+2}, \mathrm{Mn}^{+2}$, and $\mathrm{Co}^{+2}$. However, the more structurally stables compositions possesses partial substitution with trivalent cations, such as $\mathrm{Sc}^{+3}, \mathrm{Al}^{+3}, \mathrm{Fe}^{+3}$, and $\mathrm{Cr}^{+3}$ (Cavani et al., 1991, Crepaldi e Valim, 1998).

Depending on the combination of divalent and trivalent cations, the structure can present different adsorptive properties and also great variation in thermal stability, in the face of interlayer space dehydration and lamellae dehydroxylation processes (Shekoohi, 2017; Timofeeva et al., 2016).

When hydrotalcite compositions have part of the divalent cations substituted by other divalent cations, the crystalline structure is fundamentally altered, mainly the thermal stability and the adsorption energy, but without causing changes in the electric charge imbalance in the layers (lamellae). In general, the lamellae may even decompose, depending on the divalent cation type and its ionic radius (Carpentier et al., 2007; Mahjoubi et al., 2016; Shannon, 1976).

However, the change in the type of trivalent cation has a greater effect on the adsorption capacity of the material, especially due to the charge imbalance of lamella caused by the substitution, but also by differences in chemical affinity, generally due to variations in the binding properties of the transition metal cations (Bolognini et al., 2002; Obalová et al., 2005; Rao et al., 1998; Rodilla et al., 2015; Zhou et al., 2016; Wu et al., 2008).

Several synthetic hydrotalcite compositions are used in medicine as biocompatible matrices for drug delivery. In contrast to natural clays, the synthetic ones have higher purity and tunable composition in order to avoid no toxic components. Thus, the hydrotalcites are often used as medicines for the treatment of severe ulcers, since it is a double hydroxide very similar to its individual hydroxide suspensions available in pharmacies (Konturek et al., 2007; Holtmeier et al., 2007).
In addition to this versatility of applications, hydrotalcites appear to be the most effective for ion exchanging, being able to incorporate several anions, such as carbonate $\mathrm{CO}_{3}{ }^{-2}$, fluoride $\mathrm{F}^{-}$, sulfate $\mathrm{SO}_{4}{ }^{-2}$, nitrate $\mathrm{NO}_{3}{ }^{-}$, phosphate $\mathrm{PO}_{4}{ }^{-3}$, amines $\mathrm{RNH}_{2}$, and ammonia $\mathrm{NH}_{3}$. This feature gives the material a high performance for water purification (Brindley e Kikkawa, 1979; Ma et al., 2011; Deng et al., 2014).

The most common hydrotalcites are composed of magnesium partially replaced by aluminum, due to the similarity with natural clays and because they are also more structurally stable, especially when the partial replacement of aluminum is between 20 and $33 \%$. However, the most stable and crystalline compositions are observed for maximum aluminum contents, although these parameters can also vary significantly with the age of the precipitate aging in the mother solution and other experimental parameters (Carpani et al., 2006; Del Arco et al., 1999; Niu et al., 2016; Shen et al., 1994).

Synthetic hydrotalcites can be obtained with high purity without major complications from experimental procedures. There are several different synthesis methods for obtaining this material, such as Hydrothermal, Sol-Gel, Microwave Synthesis, Urea Hydrolysis, Electrochemical Synthesis, SaltOxide Synthesis and Hydroxide Coprecipitation, which the last cited method was used in this work (Fahami e Beall, 2016; Reichle et al., 1986; Wiyantoko et al., 2015).

In a broad and general way, it can be said that any carbonated hydrotalcite structure has thermal stability superior to others, but undergoes thermal decomposition in three stages. First, a process of superficial dehydration occurs followed by interlayer dehydration, which can sometimes occur in an overlapping manner up to a temperature of $250{ }^{\circ} \mathrm{C}$. Then, at immediately higher temperatures, the lamellae dehydroxylation begins to occur, which largely depends on the individual thermal stability of the metal hydroxides present in the material (Puttaswamy e Kamath, 1997)

This stage can extend up to over $400{ }^{\circ} \mathrm{C}$, depending on the composition, and can accelerate the last stage of decomposition, which is interlayer decarbonation. Depending on the composition, hydrotalcite structures not yet decarbonated can be regenerated by hot rehydration, since the anchoring of the carbonate anion gives structural memory to hydrotalcite (Basag et al., 2017; Rhee e Kang, 2002).

In this work, it was proposed to study the thermal and morphological behaviors of a composition of carbonated hydrotalcite of magnesium-aluminum when there is cosubstitution between aluminum and chromium (III) trivalent cations and to compare these behaviors to those presented for a common composition of carbonated hydrotalcite of magnesium-aluminum.

\section{MATERIAL AND METHODS}

Two hydrotalcite compositions were synthesized by the hydroxide precipitation process, with the molar ratio of the divalent magnesium cation set at 0.7 and the trivalent cations at 
0.3. In the reference sample, the trivalent cation includes only aluminum, represented by the general formula of the anhydrous composition given by $\mathrm{Mg}_{0,7} \mathrm{Al}_{0,3}(\mathrm{OH})_{2}\left(\mathrm{CO}_{3}\right)_{0,15}$, which was called the HTM7A3 sample. In the other sample, 0.2 mol of aluminum was substituted by chromium III, which anhydrous composition is $\mathrm{Mg}_{0,7} \mathrm{Al}_{0,1} \mathrm{Cr}_{0,2}(\mathrm{OH})_{2}\left(\mathrm{CO}_{3}\right)_{0,15}$ and was named HTM7AC2.

The synthesis process of the two samples occurred with all the experimental parameters set, except for the variation in composition. Thus, for the HTM7A3 sample, a cation mix aqueous solution was obtained by dissolving the stoichiometric amounts of magnesium nitrate II hexahydrate $\mathrm{Mg}\left(\mathrm{NO}_{3}\right)_{2} \cdot 6 \mathrm{H}_{2} \mathrm{O}$ (Vetec) and aluminum nitrate III nonahydrate $\mathrm{Al}\left(\mathrm{NO}_{3}\right)_{3} .9 \mathrm{H}_{2} \mathrm{O}$ (Dynamic). For the HTM7AC2 sample, co-substituted with chromium (III), a new cation mix aqueous solution was obtained by dissolving stoichiometric amounts of chromium nitrate III nonahydrate $\mathrm{Cr}\left(\mathrm{NO}_{3}\right)_{3} .9 \mathrm{H}_{2} \mathrm{O}$ (Vetec) in partial substitution of aluminum nitrate reagent.

In parallel, two other similar solutions, called precipitant solutions, were prepared by dissolving stoichiometric amounts of sodium hydroxide $\mathrm{NaOH}$ (Dynamic) and sodium carbonate $\mathrm{Na}_{2} \mathrm{CO}_{3}$ (Vetec). Each sample was precipitated in a reaction beaker already containing an aqueous solution of $\mathrm{NaOH}$ in $\mathrm{pH} \mathrm{11,} \mathrm{which} \mathrm{is} \mathrm{kept} \mathrm{under} \mathrm{vigorous}$ stirring while simultaneously adding the precipitant and cation mix solutions of each sample, in a slow and continuous way until total precipitation.

Then, the samples were heated to $80^{\circ} \mathrm{C}$ and kept under moderate agitation for 6 hours for the ageing process, remaining at rest at room temperature for 18 hours for sedimentation (Figure 1). Each sample was then filtered under vacuum and washed with distilled water with purification control through the multi-parameter of Hanna Company, model HI9828 - pH/ORP/EC/DO. The purified samples were dried at $100{ }^{\circ} \mathrm{C}$ during 24 hours in a drying oven with forced air circulation and characterized by Thermal Analysis in an equipment of TA Instruments, with TGA-Q50 and DSC-Q20 modules, platinum crucibles, heating rate of $10{ }^{\circ} \mathrm{C} \mathrm{min}-1$ and synthetic air flow of $60 \mathrm{~mL} \mathrm{~min}{ }^{-1}$.
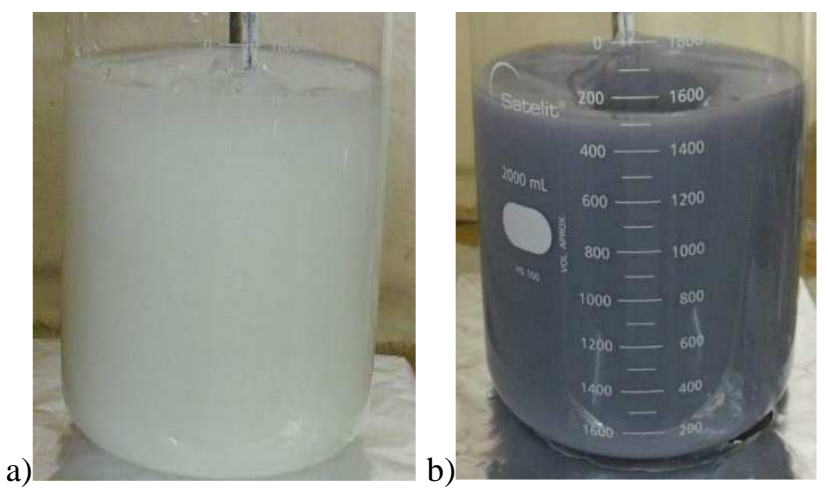

Figure 1. Precipitate suspensions during the ageing process at $80^{\circ} \mathrm{C}$ : a) HTM7A3 and b) HTM7AC2.

The samples were also characterized by X-ray diffractometry in Siemens equipment model D5005, operating with iron-filtered $\mathrm{CuK} \alpha$ radiation and the diffraction patterns were analyzed through the JCPDS diffraction database, version 2003. The samples were also characterized by Raman spectroscopy in an equipment of B\&W TekInc Company, model BWN-532-50E, operating with laser of $532 \mathrm{~nm}$.
As amostras também foram caracterizadas por Difratometria de Raios-X, usando um equipamento da Siemens D5005, operando com radiação $\mathrm{K}-\alpha$ de $\mathrm{Cu}$ filtrada com ferro. Os padrões de difração obtidos foram então analisados por comparação com o banco de dados de difração JCPDS, versão 2003. Também foram caracterizadas por espectroscopia Raman, com um equipamento da B\&W Tek Inc., modelo BWN-532-50E, operando em $532 \mathrm{~nm}$.

Finally, the morphology of the samples was investigated through nitrogen adsorption-desorption isotherms at $77 \mathrm{~K}$ using an equipment of Micromeritics company, model ASAP2010. The calculation of the specific area was made through the BET method (Marsh \& Rand, 1970) and the pore size distribution calculated through the BJH method (Landers et al., 2013).

\section{RESULTS AND DISCUSSION}

As can be seen in Figure 1, during the ageing process, it was possible to observe that the HTM7AC2 precipitate sample in suspension acquired purple like color, which is coherent with trihydroxidetriaquochromiun $\left[\mathrm{Cr}\left(\mathrm{H}_{2} \mathrm{O}\right)_{3}(\mathrm{OH})_{3}\right]$ precipitate. This color is quite different from the blue color of the hexaquochromium (III) $\left[\mathrm{Cr}\left(\mathrm{H}_{2} \mathrm{O}\right)_{6}\right]^{+3}$ complex, which is the common specie for chromium (III) cation at low $\mathrm{pH}$ values. On the other hand, the hexahydroxidechromium (III) $\left[\mathrm{Cr}(\mathrm{OH})_{6}\right]^{-3}$ green color complex, which is only predominant at very high pH values (Mendham et al., 1981; Lide, 2007).

In order to incorporate chromium hydroxide into $\mathrm{LDH}$ structure, the $\left[\mathrm{Cr}\left(\mathrm{H}_{2} \mathrm{O}\right)_{3}(\mathrm{OH})_{3}\right]$ precipitate needs to replace three water molecules by other three hydroxide groups through the dissolution-precipitation mechanism enhanced by higher temperature of ageing $\left(80^{\circ} \mathrm{C}\right)$ and constant stirring. This reordering toward the homogenous LDH structure only is possible because all of the cations in the lamellae is hexacoordinated with vicinal shared hydroxides, making the chromium substitution possible (Labajos \& Rives, 1996; Prakash et al., 2000).

The monitoring of byproducts removal through the washing process was carried out through multi parameter measurements for filtered solutions, as shown in Figure 2. It is possible to observe sharp variations on $\mathrm{pH}$ until the sixth washing act for both samples (Fig. 2.a), which is associated with the removal of the sodium hydroxide residue. From the seventh washing act, the $\mathrm{pH}$ value only oscillates around the $\mathrm{pH}$ 8. On the other hand, the conductivity presents an exponential decay variation for the HTM7A3 from 11 to 0.002 $\mathrm{mS} \mathrm{cm}^{-1}$, which value was used to define the precipitate as purified (Fig. 2.b).

The unexpected result was observed for the conductivity variation in filtered solution of HTM7AC2 sample. By considering that the filtered solution for both samples were colorless and no significant $\mathrm{pH}$ differences was observe between the samples, the higher conductivity value for HTM7AC2 sample $\left(\sim 0,02 \mathrm{mS} \mathrm{cm}^{-1}\right)$ can only be attributed to ionic product of this sample. The probable cause for this behavior can be a leaching effect of magnesium hydroxide component as function of its higher Ksp combined with some morphological aspects. 

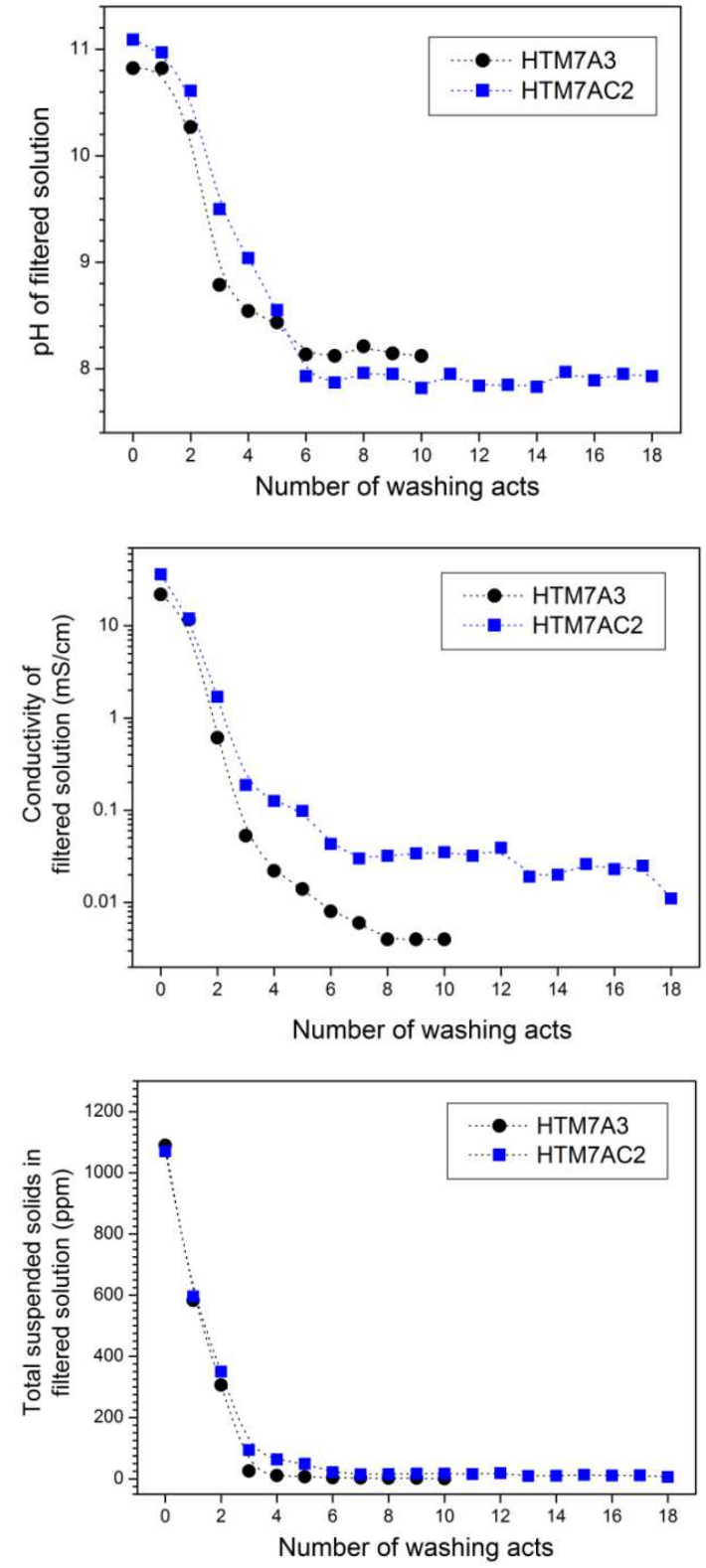

Figure 2. Variations of $\mathrm{pH}$, conductivity and total suspended solids for filtered solutions during washing acts for HTM7A3 and HTM7AC2 samples.

Figure 3 shows the pictures with purified powder samples after drying at $100{ }^{\circ} \mathrm{C}$ for 24 hours in crunching in porcelain mortar. The visual aspects of these samples are similar to observed for the respective precipitates during ageing process. Thus, the chromium seems to be inserted in LDH structure because the possible segregated phases based on chromium hydroxide, such as $\left[\mathrm{Cr}\left(\mathrm{H}_{2} \mathrm{O}\right)_{3}(\mathrm{OH})_{3}\right]$ or $\mathrm{Cr}(\mathrm{OH})_{3}$, are unstable under drying conditions, decomposing into $\mathrm{CrOOH}$, which has light green color (Barbosa et al, 2017; Lide, 2007).

The Figure 4 shows the Thermal Analysis curves (TGA/DTG/DDSC) for both purified and dried samples. It was possible to identify the following thermal events: dehydration, dehydroxylation, and decarbonation. DTG curves aims to show the interdependence between weight loss and calorimetric behavior (Ionashiro e Giolito, 1980).
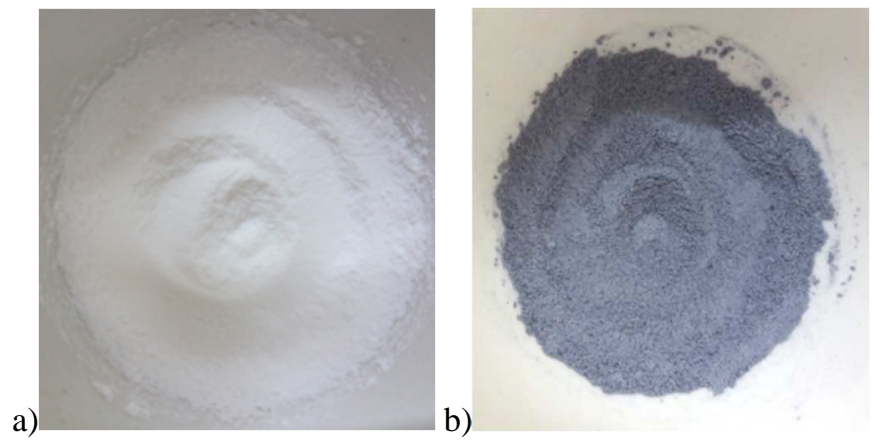

Figure 3. Visual aspect of dried samples at $100{ }^{\circ} \mathrm{C}$ after crunching: a) HTM7A3 and b) HTM7AC2.

The weight losses of the three thermal events do not differ much from each other (Table 1), but the calorimetric behavior (DSC curves) of each one is very particular. While the HTM7A3 sample (Fig. 4.a), the first weight loss (dehydration) occurs as a sharp endothermic peak at $200{ }^{\circ} \mathrm{C}$, the HTM7AC2 sample (Fig. 4.b) presents a widened endothermic DSC peak between 30 and $200{ }^{\circ} \mathrm{C}$. These results demonstrate that chromium insertion in LDH structure causes early dehydration of structure, maybe due the same morphological causes affecting the washing process.

a)

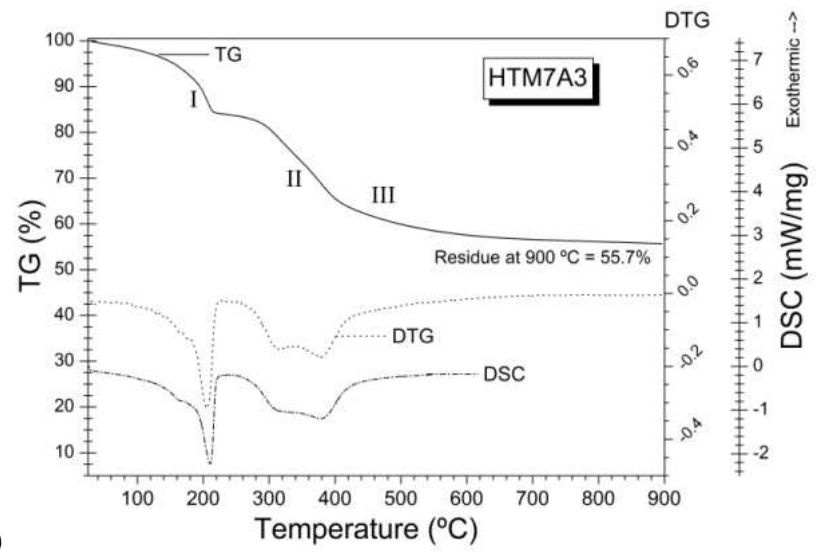

b)

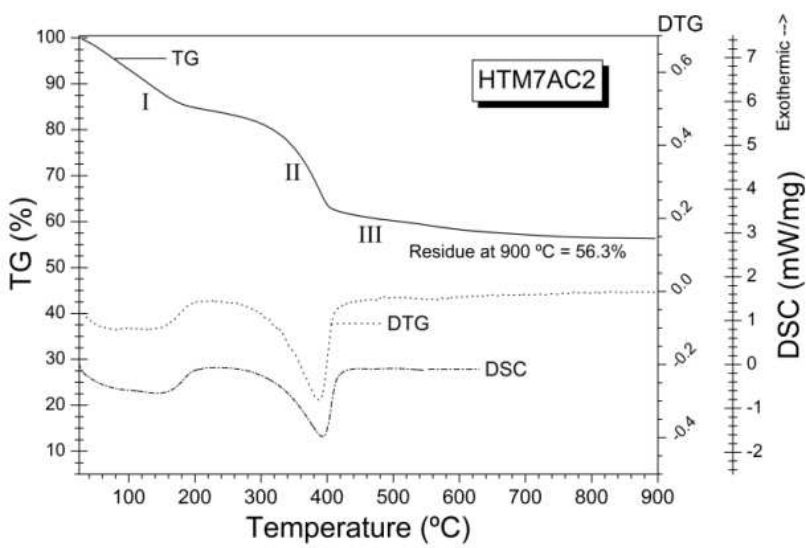

Figure 4. TGA-DTG-DSC curves of HTM7A3 and HTM7AC2 dried samples at $100{ }^{\circ} \mathrm{C}$.

For the second thermal event, associated to lamellae dehydroxylation, the DSC curves shows the inverse behavior observed for the first thermal event. Thus, even with similar weight losses, the HTM7A3 sample (Fig. 4.a) presents a widened endothermic DSC peak between 250 and $420^{\circ} \mathrm{C}$ while the HTM7AC2 sample (Fig. 4.b) presents a sharper peak localized at $390{ }^{\circ} \mathrm{C}$. 
Now, the chromium insertion seems to make the lamellae of $\mathrm{LDH}$ structure more homogenous, avoiding the early dihydroxylation process at lower temperatures. This result can be attributed to more stability of hexacoordinated chromium hydroxide, making the sharing of hydroxide groups on the lamellae stronger.

The third and stage of decomposition is the decarbonation of interlayer space, which occurs from $450{ }^{\circ} \mathrm{C}$ to $900{ }^{\circ} \mathrm{C}$, in slightly exponential decay form. It is possible to observe no DTG or DSC peaks for this process, which indicates a kinetic dependent weight loss (Giolito \& Ionashiro, 1988). Even though the molar ratio of carbonate ion is invariant between samples, the respective weight percentages are not the same because chromium is heavier than aluminum. Thus, the carbonate weight percentage is lower in HTM7AC2 sample. In addition, the morphological aspects plays an important rule on the decarbonation process, because it can be started during dehydroxylation one, if $\mathrm{LDH}$ powder material to possess high fragmented particles (Rhee e Kang, 2002), which is consistent with some results already discussed earlier.

Table 1. Weight losses and event temperatures collected form Thermal Analysis of HTM7A3 and HTM7AC2 dried samples at $100{ }^{\circ} \mathrm{C}$.

\begin{tabular}{c|c|cc}
\hline \multirow{2}{*}{ Process } & \multirow{2}{*}{$\begin{array}{c}\text { Event } \\
\text { temperature }\end{array}$} & \multicolumn{2}{|c}{ Weight loss (\%) } \\
\cline { 3 - 4 } Dehydration & $\begin{array}{c}\text { From } 30 \text { to } \\
240{ }^{\circ} \mathrm{C}\end{array}$ & 16.2 & 16.3 \\
\hline Dehydroxylation & $\begin{array}{c}\text { From } 240 \text { to } \\
450{ }^{\circ} \mathrm{C}\end{array}$ & 21.8 & 22.5 \\
\hline Decarbonation & $\begin{array}{c}\text { From } 450 \text { to } \\
900^{\circ} \mathrm{C}\end{array}$ & 6.3 & 4.9 \\
\hline Residue & $900^{\circ} \mathrm{C}$ & 55.7 & 56.3 \\
\hline
\end{tabular}

Figure 5 shows the XRD patterns for these samples. It was observed that both samples patterns correspond to the $\mathrm{R}$ $3 \mathrm{~m}$ rhombohedral phase characteristic of carbonated magnesium-aluminum hydrotalcite, according the card number 89-5434 of the JCPDS data bank. However, the samples differ greatly in crystallinity, with the HTM7AC2 sample presenting with very lower crystallinity if compared to the HTM7A3 one.

Raman spectra for these same samples are shown in Figure 6 and the results indicate the HTM7AC2 sample is less hydrated than the HTM7A3 one, due to less Raman scattering for smaller wavenumbers. The excessively wide band at referred wavenumber region is consequence of SERS effect caused by hydrogen bonds between water molecules in interlayer space and the hydroxide groups on lamella surface (Socrates, 2004; Zhang et al., 2019).

On the other hand, the HTM7AC2 sample has sharper band located at higher wavenumber, which is associated with hydroxyl groups of the lamellae. Considering that both the amount of hydration water and the amount of hydroxides are similar between samples, as observed in thermal analysis, it is possible to conclude the water molecules are probably more loosely linked to hydroxide groups of the lamellae for HTM7AC2 sample, what justifies the earlier dehydration form this sample.

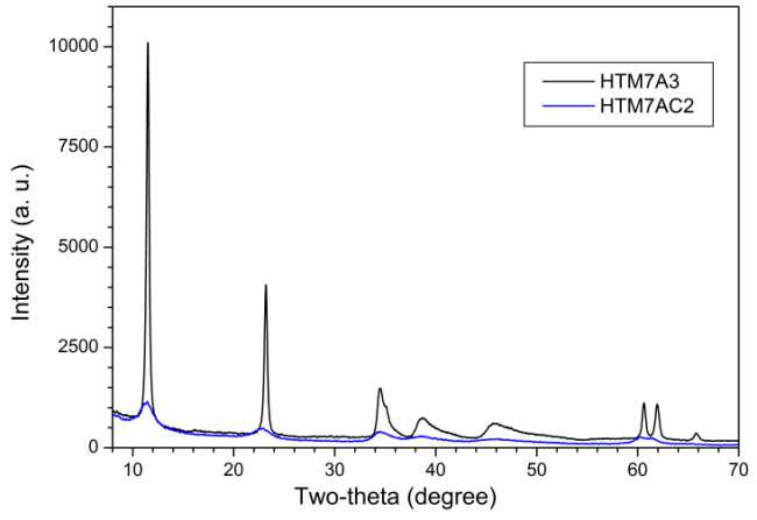

Figure 5. XRD patterns of HTM7A3 and HTM7AC2 dried samples at $100{ }^{\circ} \mathrm{C}$.

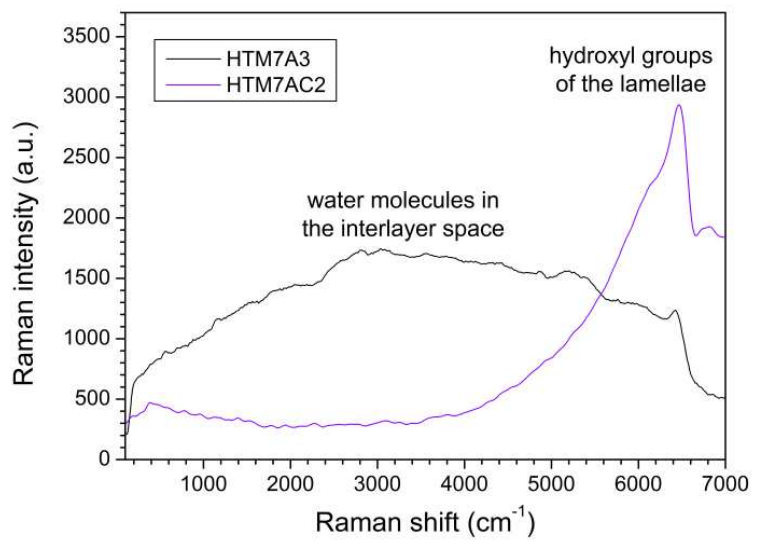

Figure 6. Raman spectra (532 nm excitation wavelength) of HTM7A3 and HTM7AC2 dried samples at $100^{\circ} \mathrm{C}$.

To evaluate how these results are affected by the morphology of the materials, these samples were characterized in terms of their adsorptive capacity through nitrogen adsorption-desorption isotherms at $77 \mathrm{~K}$. From the Isotherms presented in Figure 7.a, the B.E.T. specific areas were calculated and are shown following the sample legends in this figure. From desorption isotherm data, the $\mathrm{BJH}$ pore size distribution were obtained, as shown in Figure 7.b.

The samples showed different types of isotherms, according to the IUPAC classification (1985). The HTM7A3 sample presents a type II isotherm, which is marked by high adsorption at high relative pressures. On the other hand, the HTM7AC2 sample showed a type IV isotherm, marked by an increasing of volume adsorbed at medium relative pressures. As the adsorbed volume for the HTM7AC2 sample is higher over the entire range of relative pressure, what means this sample has greater adsorptive capacity than HTM7A3 one.

There is also hysteresis between adsorption and desorption at intermediate pressures for the HTM7AC2 sample, which means the presence of a gradient of pore sizes in the region of mesopores (between 2 and $50 \mathrm{~nm}$ ) and macropores (greater than $50 \mathrm{~nm}$ ).

Macropores contribute to the largest specific area in this sample (Gregg \& Sing, 1982; Lowell et al., 2004). Thus, the specific surface area of the HTM7AC2 sample is almost four times greater than that of the HTM7A3 sample, as can be seen in the pore size distribution curves (Figure 7.b). 

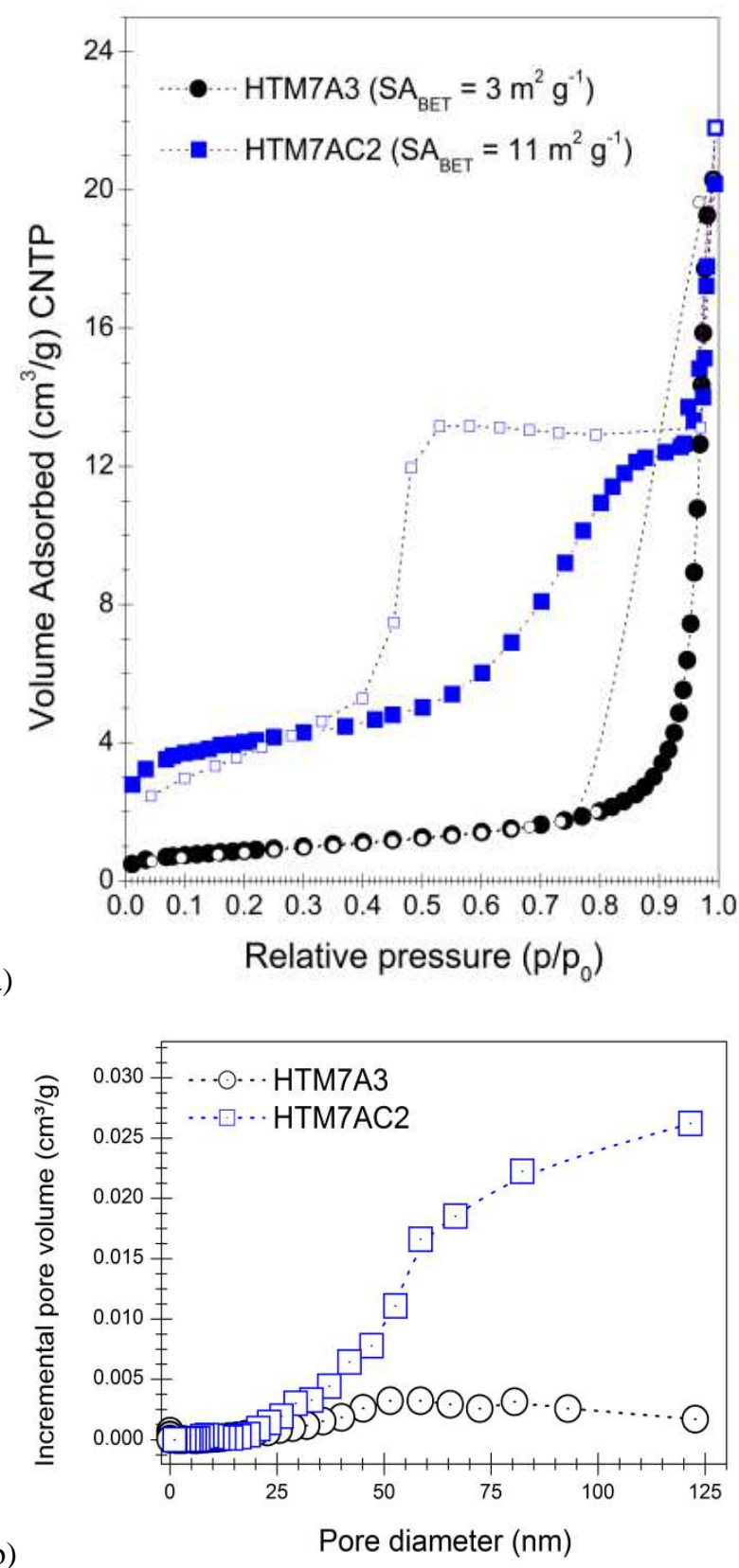

Figure 7. Nitrogen adsorption/desorption isotherms at $77 \mathrm{~K}$ (a) and BJH pore-size distribution (b) of HTM7A3 and HTM7AC2 dried samples at $100{ }^{\circ} \mathrm{C}$.

\section{CONCLUSION}

The hydroxide precipitation method at $\mathrm{pH} 11$ followed by ageing process at $80{ }^{\circ} \mathrm{C}$ has proved to be suitable for obtaining LDH structure of carbonated magnesium-aluminum hydrotalcite samples even when co-substituted with chromium (III). Both samples presented weight losses characteristic of the thermal events, but the DSC profile of these events indicated to have a different interaction between water molecules in interlayer space and hydroxide groups in lamellae. Through the Raman spectra for theses samples, it was possible to discover the causes for this behavior. In addition, the results of XRD and pore size distribution showed that chromium causes a turbostratic effect in LDH structure, which was evidenced by the lower crystallinity and more opened structure, respectively.

\section{ACKNOWLEDGMENTS}

The authors of this work are grateful to the Postgraduate Program in Natural Resources at UEMS (PGRNUEMS) and the financial contributions from PIBAP-UEMS, CNPq and FUNDECT-MS.

\section{R E F E R E N C E S}

BARBOSA, G. V.; ZAGHETE, M. A.; AMORESI, R. A. C.; SILVA, M. S.; CAVALHEIRO, A. A.; SILVA, R. C. L. Structural Analysis of Magnesium-Aluminium Hydrotalcites Modified with Iron III Obtained by Hydroxide Precipitation Method. Materials Sciences And Applications, V. 08, p. 784-797, 2017.

BASAG, S.; KOVANDA, F.; PIWOWARSKA, Z.; KOWALCZYK, A.; PAMIN, K.; CHMIELARZ, L. Hydrotalcite-derived Co-containing mixed metal oxide catalysts for methanol incineration. Journal of Thermal Analysis and Calorimetry, V.129, n. 3, p. 1301-1311, 2017.

BELLOTO, M.; REBOURS, B.; CLAUSE, O.; LYNCH, J.; BAZIN, J. L. D.; ELKAÏN, E. Hydrotalcite Decomposition Mechanism: A clue to the struture and Reactivity of spinel-like Mixed Oxides. The Journal of Physical Chemistry, V. 100, p. 8535-8542, 1996.

BOLOGNINI, M.; CAVANI, F.; SCAGLIARINI, D.; FLEGO, C.; PEREGO C.; SABA M.. Heterogeneous basic catalysis as alternatives to homogeneous catalysts: reactivity of $\mathrm{Mg} / \mathrm{Al}$ mixed oxides in the alkylation of mcresol with methanol. Catalysis Today, v. 75, p. 103111, 2002.

BRINDLEY, G. W., KIKKAWA, S. A Crystal-Chemical Study of $\mathrm{Mg}, \mathrm{Al}$ and $\mathrm{Ni}, \mathrm{Al}$ Hydroxy-Perchlorates and Hydroxy-Carbonates. American Mineralogist, v. 64, p. 836-843, 1979.

CARPANI, I.; BERRETTONI, M.; GIORGETTI, M.; TONELLI, D. Intercalation of Iron(III) Hexacyano Complex in a Ni,Al Hydrotalcite-like Compound. The Journal of Physical Chemistry B, V. 110, p. 72657269, 2006.

CARPENTIER, J.; SIFFERT, S.; LAMONIER, J. F.; LAVERSIN, H.; Aboukais, A. Synthesis and characterization of $\mathrm{Cu}-\mathrm{Co}-\mathrm{Fe}$ hydrotalcites and their calcined products. Journal of Porous Materials, v. 14, p. 103-110, 2007.

CAVANI, F.; TRIFIRÓ, F.; VACCARI, A. Hydrotalcite Type anionic clays: Preparation, properties and applications. Catalysis Today, v. 11, p. 177-301, 1991.

CREPALDI, E. L.; VALIM, J. B. Hidróxidos Duplos Lamelares: Síntese, Estrutura, Propriedades e Aplicações. Química Nova, V. 21, n. 3, p. 300-311, 1998.

DEL ARCO, M.; MALET, P.; TRUJILLANO, R.; RIVES, V. Synthesis and Characterization of Hydrotalcites Containing $\mathrm{Ni}(\mathrm{II})$ and $\mathrm{Fe}(\mathrm{III})$ and Their Calcination 
Products. Chemistry of Materials, V. 11, n. 3, p. 624633, 1999.

DENG, L.; SHI, Z.; LI, B.; YANG, L.; LUO, L.; YANG, X. Adsorption of $\mathrm{Cr}(\mathrm{VI})$ and Phosphate on $\mathrm{Mg}-\mathrm{Al}$ Hydrotalcite Supported Kaolin Clay Prepared by Ultrasound-Assisted Coprecipitation Method Using Batch and Fixed-Bed Systems. Industrial Engineering Chemistry Research, V. 53, p. 7746-7757, 2014.

FAHAMI, A.; BEALL, G. W. Mechanosynthesis and characterization of Hydrotalcite like Mg-Al-SO4-LDH. Materials Letters, V. 165, p. 192-195, 2016.

GIOLITO, I.; IONASHIRO, M. A nomenclatura em análise térmica parte II. Cerâmica, V. 34, n. 225, p. 163-164, 1988.

GREGG, S. J.; SING, K. S. W.; Adsorption, Surface Area and Porosity, Ed. Academic Press, Inc. 1982.

HOLTMEIER, W.; HOLTMANN G.; CASPARY, W. F.; WEINGÄRTNER, U.; On-demand treatment of acute heartburn with the antacid hydrotalcite compared with famotidine and placebo: randomized double-blind cross-over study. Journal of Clinical Gastroenterology, V. 41, n. 6, p. 564-570, 2007.

IONASHIRO, M. GIOLITO Fundamentos de Termogravimetria a Análise Térmica Diferencial/Calorimetria Exploratória Diferencial. São Paulo-SP: Giz Ed., 2004. 98p.

IUPAC - Comission on Colloid and Surface Chemistry Including Catalysis. Pure Applied Chemistry. V. 57, p. 603-619, 1985.

JCPDS - Joint Committee on Powder Diffraction Standards/International Center for Diffraction Data, Pennsylvania, Powder Diffraction File 2003.

KONTUREK, J. W.; BENEKE, M.; KOPPERMANN, R.; PETERSEN-BRAUN, M.; WEINGÄRTNER, U. The efficacy of hydrotalcite compared with OTC famotidine in the on-demand treatment of gastroesophageal reflux disease: a non-inferiority trial. Medical Science Monitor: International Medical Journal of Experimental and Clinical Research, V. 13, n. 1 p. 44-49, 2007.

LABAJOS, F. M.; RIVES, V. Thermal Evolution of Chromium (III) Ions Hidrotalcitelike Compounds. Inorganic Chemistry, V.34, p. 5313-5318, 1996.

LANDERS, J.; GOR, G. Y.; Neimark, A. V. Density functional theory methods for characterization of porous materials. Colloids and Surfaces A: Physicochemical and Engineering Aspects, V. 437, p. 3-32, 2013.

LIDE, D. R.; Handbook of Chemistry and Physics, 87th Edition, ed., Taylor and Francis, Boca Raton, FL, 2007.

LOWELL, S.; Shields, J. E.; Thomas, A. M.; Thommes, M. Caracterization of porous solids and powerds: Surface Area, Pore Size and Density. Philip Drive, Norwell, MA 02061, EUA: Kluwer Academic Publishers, p. $282,2004$.

MA, W.; ZHAO, N.; YANG, G.; TIAN, L.; WANG, R. Removal of fluoride ions from aqueous solution by the calcination product of $\mathrm{Mg}-\mathrm{Al}-\mathrm{Fe}$ hydrotalcite-like compound. Desalination, V. 268, p. 20-26, 2011.

MAHJOUBI, F. Z.; KHALIDI, A.; ABDENNOURI, M.; BARKA, N. M-Al-SO4 layered double hydroxides $(\mathrm{M}=\mathrm{Zn}, \mathrm{Mg}$ or $\mathrm{Ni})$ : synthesis, characterization and textile dyes removal efficiency. Desalination and Water Treatment, V. 57, n. 45, p. 21564-21576, 2016.

MARSH, H.; RAND, B. Adverse criticism of the use of the tplot to characterize microporosity. Journal of Colloid and Interface Science, V. 33, p. 478-479, 1970.

MENDHAM, J.; DENNEY, R. C.; BARNES, J. D.; THOMAS, M. J. K. - Vogel: Análise Química Quantitativa. $4^{\text {a }}$ ed. (Traduzido por Aïda Espinola, COPPE - UFRJ), Rio de Janeiro, Guanabara Dois, 1981, p. 690 .

NIU, M.; QIU, M.; HAN, Q.; WANG, Y. The Influence on Synthetising Mg-Al Hydrotalcite by Using Different $\mathrm{Mg}$ and $\mathrm{Al}$ Sources as the Precursors. American Chemical Science Journal, V. 15, n. 3, p. 1-7, 2016.

OBALOVÁ, L.; JIRÁTOVÁ, K.; KOVANDA, F.; PACULTOVÁ, K.; LACNÝ, Z.; MIKULOVA, Z. Catalytic decomposition of nitrous oxide over catalysts prepared from $\mathrm{Co} / \mathrm{Mg}-\mathrm{Mn} / \mathrm{Al}$ hydrotalcite-like compounds. Applied Catalysis B Environmental, V. 60 , p. 289-297, 2005.

PRAKASH, A. S.; KAMATH, V.; HEGDE, M. S. Synthesis and characterization of the layered double hydroxides of $\mathrm{Mg}$ with Cr. Materials Research Bulletin, V. 35, p. 2189-2197, 2000.

PUTTASWAMY, N. S.; KAMATH, V. Reversible thermal behaviour of layered double hydroxides a thermogravimetric study. Journal of Materials Chemistry, V.7, n. 9, p. 1941-1945, 1997.

RAO, K. K.; GRAVELLE, M.; VALENTE, J. S.; FIGUERAS, F. Ativation of MgAl Hidrotalcite Catalyst for Aldol Condensation Reactions. Journal of Catalysis, V. 173, p. 115-121, 1998.

REICHLE, W. T.; KANG, S. Y.; EVERHARDT, D. S. The Nature of the Thermal Decomposition of a Catalytically Active Anionic Clay Mineral. Journal of Catalysis, V. 101, p. 352-359, 1986.

RHEE, S. W.; KANG, M. Kinetics on Dehydration Reaction during Thermal Treatment of MgAl-CO3-LDHs. Korean Journal of Chemical Engineering, V. 19, n. 4, p. 653-657, 2002.

RODILLA, J. M.; NEVES, P. P.; POMBALA, S.; RIVES, V.; TRUJILLANO, R.; DÍEZC, D. Hydrotalcite catalysis for the synthesis of new chiral building blocks. Natural Product Research, V. 30, p. 834-840, 2015.

SHANNON, R. D. Revised effective ionic radii and systematic studies of interatomic distances in halides and chalcogenides. Acta Crystallographica A32, p. 751767, 1976.

SHEKOOHI, K.; HOSSEINI, F. S.; HAGHIGHI, A. H.; SAHRAYIAN, A. SAHRAYIAN, A. Synthesis of Some Mg/Co-Al Type Nano Hydrotalcites and characterization. MethodsX, V. 4, p. 86-94, 2017. 
SHEN, J.; KOBE, J. M.; CHEN, Y.; DUMESIC, J. A. Synthesis and Surface Acid/Base Properties of Magnesium-Aluminum Mixed Oxides Obtained from Hydrotalcites. Langmuir, V. 10, p. 3902-3908, 1994.

SOCRATES, G. Infrared and Raman Characteristic Group frequencies, $3^{\text {th }}$ ed., John Wiley e Sons, Chichester, 2004.

TIMOFEEVA, M. N.; KAPUSTIN, A. E.; PANCHENKO, V. N.; BUTENKO, E. O.; KRUPSKAYA, V. V.; GIL, A.; VICENTE, M. A. Synthetic and natural materials with the brucite-like layers as high active catalyst for synthesis of 1-methoxy-2-propanol from metanol and propylene oxide. Journal of Molecular Catalysis A: Chemical, V. 43, p. 22-30, 2016.

VELU, S.; SWAMY, C. S. Effect of substitution of Fe3+/Cr3+ on the alkylation of phenol with methanol over magnesium-aluminium calcined hydrotalcite. Applied Catalysis A: General, V. 162, p. 81-91, 1997.

WIYANTOKO, B.; KURNIAWATI, P.; PURBANINGTIAS, T. E.; FATIMAH. I. Synthesis and Characterization of Hydrotalcite at Different Mg/Al Molar Ratios. Procedia Chemistry, V.17 p. 21-26, 2015.
WU, G.; WANG, X.; LI, J.; ZHAO, N.; WEI, W.; SUN, Y. A new route to synthesis of sulphonato-salenchromium(III) hydrotalcites: Highly selective catalysts for oxidation of benzyl alcohol to benzaldehyde. Catalysis Today, V. 131, p. 402-407, 2008.

YANG, Y.; GAO, N.; CHU, W.; ZHANG, Y.; MA, Y. Adsorption of perchlorate from aqueous solution by the calcination product of $\mathrm{Mg} /(\mathrm{Al}-\mathrm{Fe})$ hydrotalcite-like compounds. Journal of Hazardous Materials, V. 209210, p. 318-325, 2012.

ZHOU, W. Y.; PAN, J. G.; WU, Z.; QIAN, J. F.; HE, M. Y.; CHEN, Q. Efficient catalytic oxidation of alcohol to carbonyl compounds over CoFe hydrotalcites. RSC Advances, V. 6, p. 84106-84112, 2016.

ZHANG, Y.; ZHANG, L.; HU, L.; HUANG, S.; JIN, Z.; ZHANG, M.; HUANG, X.; Lu, J.; RUAN, S.; ZENG, Y.-J. Multifunctional Zn-Al layered double hydroxides for surface-enhanced Raman scattering and surfaceenhanced infrared absorption. Dalton Transactions, V. 48, p. 426-434, 426. 2019. 